\title{
Treatment of succinonitrile wastewater by immobilized high efficiency microorganism strains
}

\author{
X. F. Zhou, Y. L. Zhang, D. Q. Xu, W. H. Cao, C. M. Dai, Z. M. Qiang, \\ Z. Yang and J. F. Zhao
}

\begin{abstract}
Using succinonitrile as a sole source of carbon and nitrogen, two bacterium strains named as J-1-3 and J-13-1 were isolated and screened out from the treatment facilities of Shanghai petrochemical wastewater treatment plant treating acrylic fiber production wastewater. The optimal growth conditions of the two strains in the degradation of succinonitrile with varied initial concentrations were determined through flask tests as follows: temperature $30^{\circ} \mathrm{C}$, shaker rotary speed of $250 \mathrm{r} / \mathrm{min}$, inoculum percentage $0.1 \%$, and initial $\mathrm{pH}$ 6. Results indicate that the two strains, especially J-13-1, exhibited a high efficiency for succinonitrile degradation. Thereafter, the bacterium strains were immobilized separately by sodium alginate and polyvinyl alcohol $1750 \pm 50$, and applied to succinonitrile degradation again. Results show that in a very broad range of the initial succinonitrile concentration, i.e., $30-5,000 \mathrm{mg} / \mathrm{L}$, the sodium alginate immobilized grains could degrade more than $80 \%$ of succinonitrile after $24 \mathrm{~h}$ under the experimental conditions of $30^{\circ} \mathrm{C}, \mathrm{pH} 6.5$, and shaker rotary speed of $250 \mathrm{r} / \mathrm{min}$. However, the polyvinyl alcohol immobilized grains tended to inflate and break down due to a weak mechanical strength.

Key words | bacterium strains, high efficiency, immobilized grains, Isolation, succinonitrile wastewater

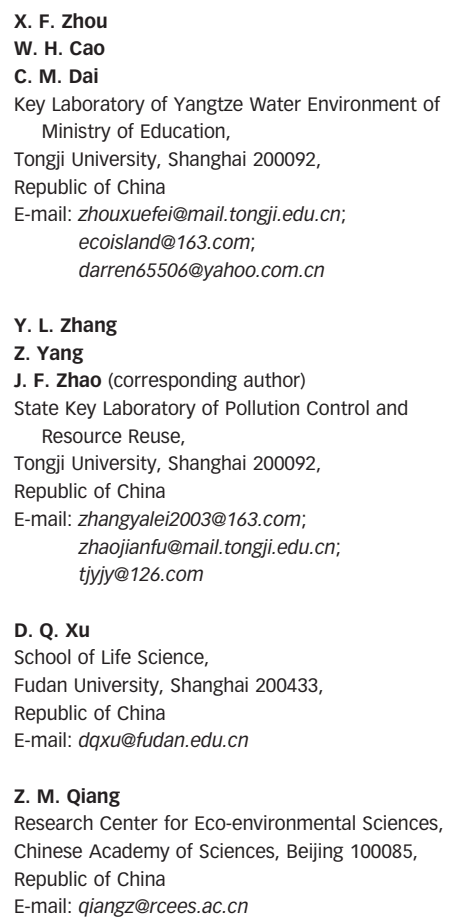

\section{INTRODUCTION}

Many kinds of synthetic aliphatic nitrile compounds have been widely used in the production of solvents, extractants, pharmaceuticals, plastics and other petrochemical and chemical fiber products. The direct discharge of wastewater containing some of these nitrile compounds could possibly cause severe health hazards because most of them are highly toxic and some are mutagenic and carcinogenic (Nawaz et al. I99I). Therefore, the wider use of these toxic compounds could lead to an environmental problem in the future.
Though nitrile compounds have acute toxicity to microorganisms, some bacteria may degrade them after incubation (Hadri et al. 2005; Huang et al. 2007). The biodegradation of nitrile compounds, such as acetonitrile and acrilonitrile, has been studied extensively (Yamada et al. I979; Wang et al. 2004; Akamatsu et al. 2007; Li et al. 2007). In addition, microbial degradation of other individual nitrile compounds and their derivatives has been reported by some researchers using different strains, such as Pseudomonas (Dhillon \& Shivaraman I999), Pseudomonas putida 
(Nawaz et al. I989), Pseudomonas sp. strain K9 (Yamada et al. I980), Pseudomonas stutzeri (Wang et al. 200I). However, there is little research up to date on the biodegradation of succinonitrile which is considered to be recalcitrant to microorganisms and latently toxic to human being, animals and plants. It is one of the main pollutants present in the acrylic fiber production wastewater usually with a high concentration (Zhang I999).

The objectives of this work were: 1 ) isolate and screen out bacterium strains effective in succinonitrile degradation from the acrylic fiber production wastewater treatment facilities; 2) determine the optimal growth conditions for the isolated strains through flask tests; and 3) immobilize the isolated strains on different carriers for effective degradation of succinonitrile. The immobilization methods using sodium alginate and polyvinyl alcohol 1,750 \pm 50 have been reported by other researchers (Yao et al. 2003; Lin et al. 2006; Su et al. 2006; Hayashi et al. 2007; Toniazzo et al. 2007).

\section{MATERIALS AND METHODS}

\section{Materials}

\section{Substrate and materials for immobilization}

Succinonitrile (98\%) was obtained from Lancaster Synthesis Company. Sodium alginate and polyvinyl alcohol 1,750 \pm 50 (PVA) were purchased from Shanghai Chemical Reagent Company of China Medical Group with a purity of $>99.0 \%$.

\section{Media}

The broth medium was prepared according to the literature (Hu \& Zhou I988). Yamada enrichment medium was prepared as follows: glucose $0.5 \mathrm{~g}$, peptone $1.0 \mathrm{~g}, \mathrm{KH}_{2} \mathrm{PO}_{4}$ $0.1 \mathrm{~g}, \mathrm{MgSO}_{4} \cdot 7 \mathrm{H}_{2} \mathrm{O} 0.1 \mathrm{~g}$, distilled water $1 \mathrm{~L}$, and $\mathrm{pH} 7.0$ (Yamada et al. I979). Yamada base medium was prepared as follows: $\mathrm{K}_{2} \mathrm{HPO}_{4} 2.0 \mathrm{~g}, \mathrm{NaCl} 1.0 \mathrm{~g}, \mathrm{MgSO}_{4} \cdot 7 \mathrm{H}_{2} \mathrm{O} 0.2 \mathrm{~g}$, $\mathrm{VH} 2 \mu \mathrm{g}$, calcium pantothenate $0.4 \mathrm{mg}$, inose $2 \mathrm{mg}$, niconacid $0.4 \mathrm{mg}$, VB1- $\mathrm{HCl} 0.4 \mathrm{mg}, \mathrm{VB} 6-\mathrm{HCl} 0.4 \mathrm{mg}$, para-aminobenzoic acid $0.2 \mathrm{mg}$, VB2 $0.2 \mathrm{mg}$, folic acid $0.01 \mathrm{mg}$, distilled water $1 \mathrm{~L}, \mathrm{pH} 7.0$. Agar powder of $16 \mathrm{~g}$ was added to the solid culture medium (Yamada et al. 1979). The ingredients of B.B. base medium was obtained by taking off the nitrogen source from Bushnell - Hall base medium (Bushnell \& Haas I94I). Its composition was as follows: $\mathrm{MgSO}_{4} 0.2 \mathrm{~g}, \mathrm{KH}_{2} \mathrm{PO}_{4} 1.0 \mathrm{~g}$, $\mathrm{CaCl}_{2} 0.02 \mathrm{~g}, \mathrm{~K}_{2} \mathrm{HPO}_{4} 1.0 \mathrm{~g}, 2$ drops of concentrated $\mathrm{FeCl}_{3}$ solution, distilled water $1 \mathrm{~L}$. The medium $\mathrm{pH}$ was adjusted to 5.0, 6.0, 7.0, 8.0, and 9.0 in the experiments for optimal $\mathrm{pH}$ determination, and maintained 6.0 in other experiments.

\section{Preparation of immobilized cells}

When immobilizing the isolated strains with sodium alginate, the wet cells were repeatedly purified on the incubation media for three times, and mixed with $4 \%$ sodium alginate glues at a 1:40 ratio of wet cell weight to sodium alginate glue volume (i.e., cell to glue ratio, g/mL). The mixture was added dropwise into a $\mathrm{CaCl}_{2}$ solution of $4^{\circ} \mathrm{C}$ to form gel grains, and then placed in a refrigerator at $4^{\circ} \mathrm{C}$ to continue the reaction for $24 \mathrm{~h}$. By this means, the immobilized grains (IMG) with a diameter of 3-4 mm were obtained and denoted as SA-IMG.

Similar procedures were adopted to immobilize the isolated strains with PVA. The wet cells were first mixed with 10\% PVA glues at a cell to glue ratio of 1:40. The mixture was then added dropwise into a saturated boric acid solution and reacted for $24 \mathrm{~h}$ at room temperature to form gel grains (denoted as PVA-IMG.). It was noted that the PVA-IMG grains tended to inflate and break down during the shaker tests, so the preparation method was modified by adding 1\% sodium alginate glue into the PVA glue attempting to enhance the mechanical strength (Anselmo 1985). The immobilization grains prepared by the modified PVA method had a diameter of 3-4 $\mathrm{mm}$ and were denoted as MPVA-IMG. However, it was found that the MPVA-IMG grains would still inflate and break down during the shaker tests though their mechanical strength was improved to some extent.

\section{Sources of wastewater and microbial inocula}

The wastewater used in this study was obtained from Shanghai petrochemical wastewater treatment plant which contained $30 \mathrm{mg} / \mathrm{L}$ succinonitrile and had a $\mathrm{pH}$ value of 6.5 . The microbial inocula were obtained from the biofilm of a biological tower filter and the wastewater of a sedimentation tank in this treatment plant. 


\section{Methods}

\section{Enrichment and isolation of bacterium strains}

Microbial samples taken from the treatment facilities of Shanghai petrochemical wastewater treatment plant were separately inoculated into $30 \mathrm{ml}$ of Yamada enrichment media contained in flasks. Succinonitrile was added into the media at a concentration of $0.5 \mathrm{~g} / \mathrm{L}$. The inoculated media were then incubated on shakers with a rotary speed of $220 \mathrm{r} / \mathrm{min}$ at $30^{\circ} \mathrm{C}$ for $3 \mathrm{~d}$. The culture solution was used as the inoculum source for fresh Yamada enrichment media to isolate bacterium strains suitable for succinonitrile degradation.

The second culture solution was inoculated into $30 \mathrm{ml}$ of Yamada base media amended with $2 \mathrm{~g} / \mathrm{L}$ succinonitrile and incubated under the same conditions as the enrichment above. This culture solution was diluted into a series of concentrations, separately coated onto the Yamada base media plates, and incubated for $3 \mathrm{~d}$ at $30^{\circ} \mathrm{C}$. Single well growing colonies were chosen for further incubation at a higher succinonitrile concentration. Thereafter, the purified strains were scribed into lines on broth media plates.

\section{Screening of bacteria strains}

Using succinonitrile as the sole source of carbon and nitrogen, the strains incubated on the broth media were inoculated into $30 \mathrm{~mL}$ of Yamada base media in $250-\mathrm{mL}$ flasks and incubated again on shakers at $30^{\circ} \mathrm{C}$ and $220 \mathrm{r} / \mathrm{min}$. The well growing strains were chosen, by measuring the turbidities of the culture solutions, for further aerobic incubation. The growth amount of strains was detected by online monitoring the optic density (OD) at $460 \mathrm{~nm}$ with a SP-1150 Visual Spectrophotometer. Eventually, the bacteria strains effective in succinonitrile degradation were screened out based on the growth rate of strains and the removal efficiency of succinonitrile.

\section{Sample analysis}

At pre-selected reaction times, the culture solution was withdrawn by syringe, filtered through a micropore membrane, and diluted with deionized water. The concentration of succinonitrile in the culture solution was analyzed with gas chromatography (HP5890). The analysis conditions were set as follows: initial oven temperature $180^{\circ} \mathrm{C}$, temperature ramp rate $30^{\circ} \mathrm{C} / \mathrm{min}$, final oven temperature $230^{\circ} \mathrm{C}$, total analysis time $4 \mathrm{~min}$, injector temperature $250^{\circ} \mathrm{C}$, detector temperature $250^{\circ} \mathrm{C}$, and injection volume $2 \mu \mathrm{L}$.

\section{Succinonitrile degradation with immobilized grains}

A desired amount of succinonitrile was added into $30 \mathrm{~mL}$ of the acrylic fiber production wastewater contained in a $250 \mathrm{~mL}$ flask to achieve a concentration of 3,000 mg/L. The SA-IMG, PVA-IMG and MPVA-IMG grains were separately added into individual flasks containing the succinonitrile wastewater to achieve a grain concentration of $2.0 \mathrm{~g} / \mathrm{L}$. The flasks were then placed on the shakers with a rotary speed of $250 \mathrm{r} / \mathrm{min}$ at $\mathrm{pH} 6.5$ and $30^{\circ} \mathrm{C}$.

\section{Effect of initial succinonitrile concentration}

Desired amounts of succinonitrile were separately added into the acrylic fiber production wastewater to achieve a final concentrations of $30,3,000$ and $5,000 \mathrm{mg} / \mathrm{L}$. The $\mathrm{pH}$ of all the succinonitrile wastewaters was adjusted to 6.5. To each flask, $30 \mathrm{~mL}$ of succinonitrile wastewater and 1.0 or $2.0 \mathrm{~g} / \mathrm{L} \mathrm{SA}-\mathrm{IMG}$ grains were added. The flasks were incubated on shakers with a rotary speed of $250 \mathrm{r} / \mathrm{min}$ at $30^{\circ} \mathrm{C}$.

\section{Degradation stability of SA-IMG}

After incubation for $24 \mathrm{~h}$, the SA-IMG grains were taken out from the flask and repeatedly washed with distilled water. Thereafter, these grains were placed into a flask containing a fresh solution of $3,000 \mathrm{mg} / \mathrm{L}$ succinonitrile and incubated again. This experiment was repeated four times to examine the degradation stability of SA-IMG.

\section{RESULTS AND DISCUSSION}

\section{Isolation and screening of bacteria strains}

Through successive isolation and screening, two bacterium strains, called J-1-3 and J-13-1, were obtained which could effectively degrade succinonitrile. 


\section{Optimal growth conditions}

Succinonitrile was added into $30 \mathrm{~mL}$ of B.B. base medium contained in 250-mL flasks as the sole source of carbon and nitrogen. The bacteria cells centrifuged from the culture solution were washed and used to prepare the suspended bacteria solution with a certain concentration. The suspended bacteria solution was inoculated into the succinonitrile amended B.B. medium, and single factor tests were carried out under varied experimental conditions, i.e., temperatures of $20,25,30,35$ and $40^{\circ} \mathrm{C}$, initial $\mathrm{pH}$ values of 5.0, 6.0, 7.0, 8.0 and 9.0, inoculum percentages (wet cell weight per litre of normal saline, $w / v$ ) of 0.01, 0.02, 0.05, 0.1 and $0.20 \%$, and shaker rotary speeds (pertinent to aeration efficiency) of 130, 160, 190, 220, and $250 \mathrm{r} / \mathrm{min}$. By detecting the optical density (OD) at $460 \mathrm{~nm}$, the growth amount of strains could be determined.

The effects of experimental conditions on the growth of strains are showed in Figures 1-5. Taking both strain growth rate and economical feasibility into consideration, the optimal growth conditions were determined as follows for both strains: incubation temperature $30^{\circ} \mathrm{C}$, shaker rotary speed $250 \mathrm{r} / \mathrm{min}$, inoculum percentage $0.1 \%$, and initial $\mathrm{pH}$ 6.0. It should be pointed out that a considerable amount of ammonia was produced during the experiments, resulting in the increase of $\mathrm{pH}$.

Succinonitrile was added into $30 \mathrm{~mL}$ of B.B. base medium contained in $250 \mathrm{~mL}$ flasks. The strains J-1-3 and J-13-1 were incubated on the medium under the optimal growth conditions determined above to examine their treatment efficiencies for succinonitrile. Figures 6 and 7

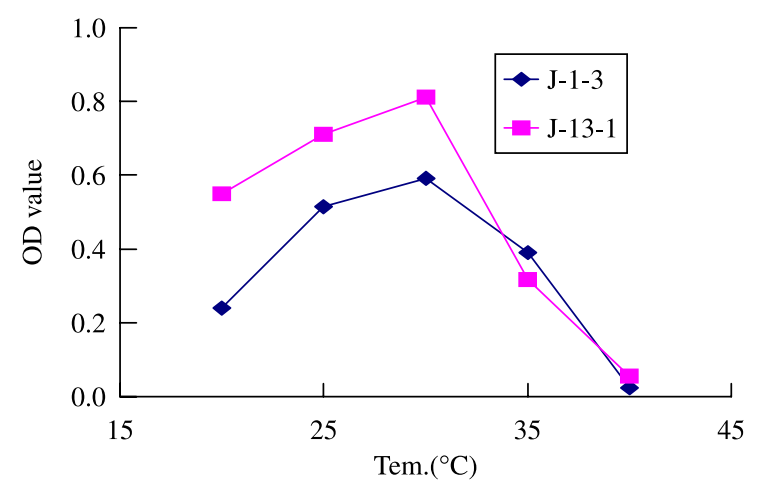

Figure 1 | Effect of temperature on growth.

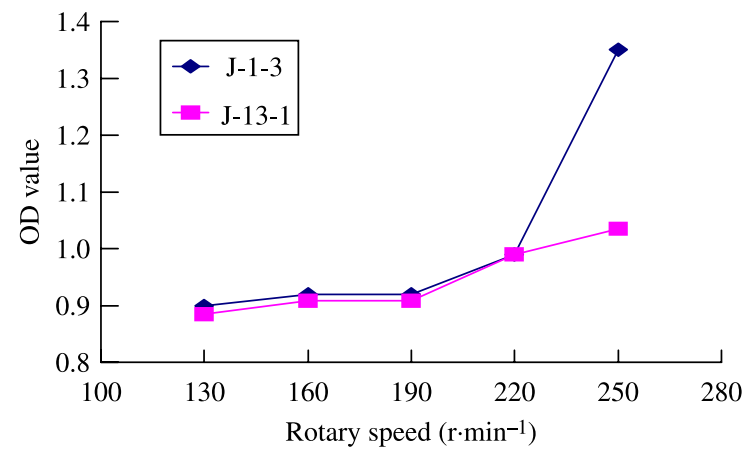

Figure 2 | Effect of shaker rotary speed on growth.

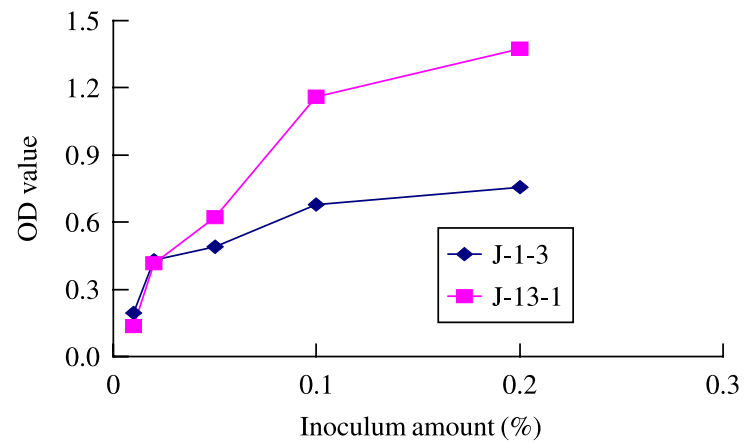

Figure 3 Effect of inoculum amount on growth.

show that both strains, particularly J-13-1, exhibited a high efficiency for succinonitrile degradation. At an initial succinonitrile concentration of 2,000 and $4,000 \mathrm{mg} / \mathrm{L}$, the removal efficiency achieved by the strain J-1-3 reached $100 \%$ after incubation for 16 and $20 \mathrm{~h}$, respectively. However, when the initial succinonitrile concentration was raised to $6,000 \mathrm{mg} / \mathrm{L}$, the removal efficiency dramatically dropped to $48 \%$ even after incubation for $24 \mathrm{~h}$.

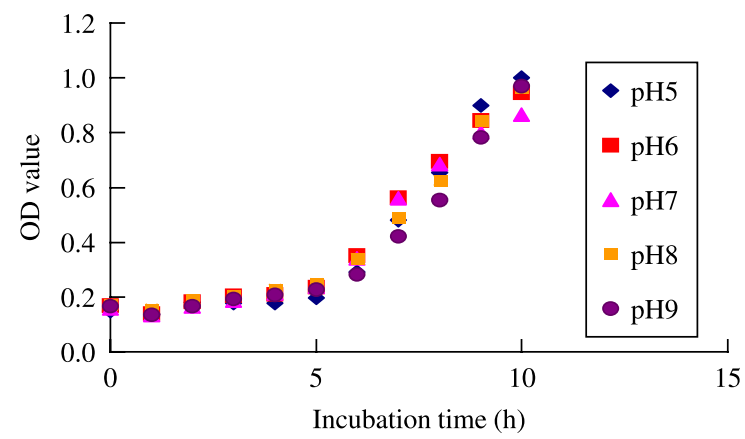

Figure 4 Effect of initial pH on growth of strain J-1-3. 


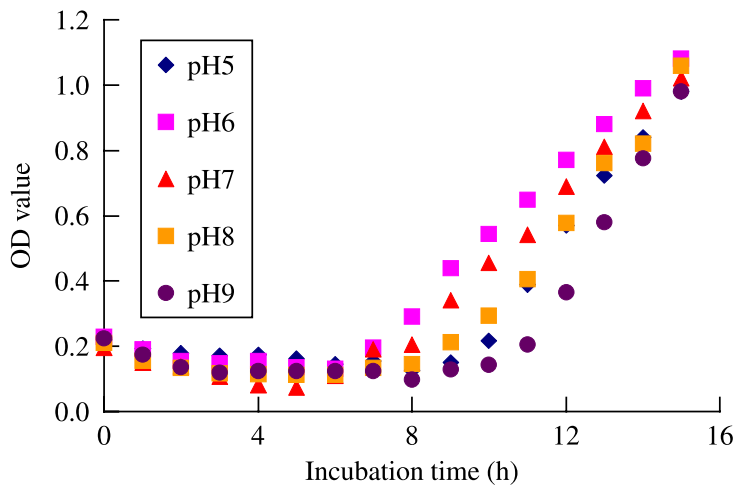

Figure 5 | Effect of initial pH on growth of strain.

Meanwhile, a complete removal of succinonitrile could be achieved by the strain J-13-1 at high initial succinonitrile concentrations of $6,000,8,000$ and $10,000 \mathrm{mg} / \mathrm{L}$ after incubation for $12.5,14$ and $16 \mathrm{~h}$, respectively. In addition, the degradation rate increased with the increasing initial concentrations of succinonitrile ranging from 2,000 to $10,000 \mathrm{mg} / \mathrm{L}$, as shown in Table 1.

According to the Figures 6 and 7, the biodegradation kinetic Equations (shown in Table 2) of succinonitrile were determined by using the linear fit. The kinetic equations and Correlation coefficient show that biodegradation of succinonitrile can be described as the first-order reaction mode.

The relation between degradation rate and initial concentration of succinonitrile can be expressed by Equation (1).

$R=\frac{R_{\max } S}{K_{\mathrm{s}}+S}$

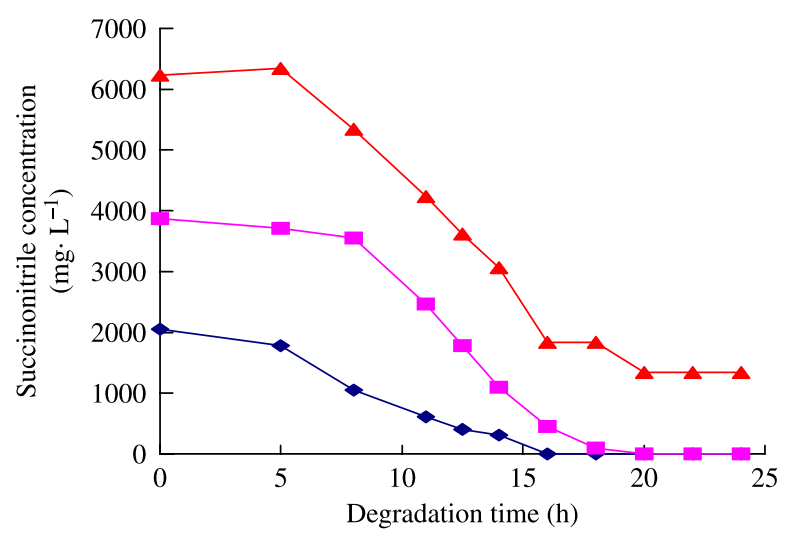

Figure 6 | Degradation of succinonitrile with different initial concentrations by strain J-1-3.

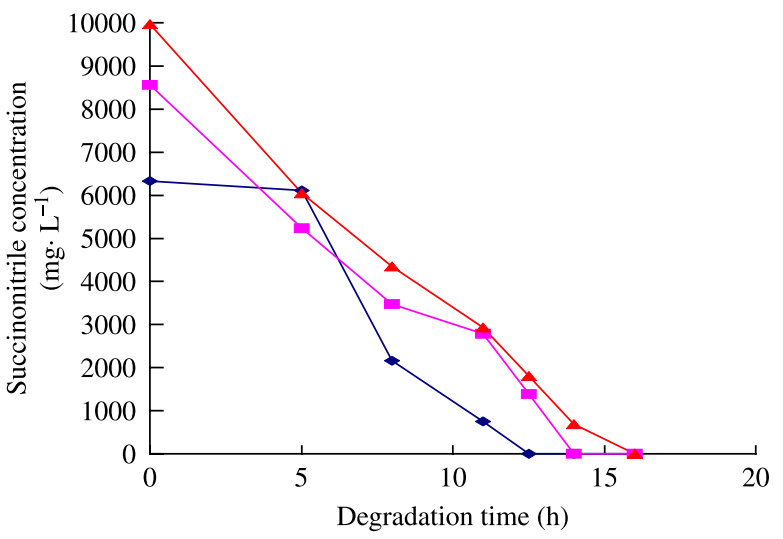

Figure 7 | Degradation of succinonitrile with different initial concentrations by strain J-13-1.

where $R_{\max }$ represents the maximum degradation rate, and $S$ is concentration of succinonitrile and $K_{\mathrm{s}}$ is the Monod' constant. Equation (1) can be linearized in the form Equation (2).

$\frac{1}{R}=\frac{1}{R_{\max }}+\frac{K_{\mathrm{S}}}{R_{\max }} \times \frac{1}{S}$

By using a linear regression analysis, the kinetic parameters of biodegradation succinonitrile by the isolated bacterium strains were obtained as shown in Table 3

\section{Identification of bacterium strains}

The strains J-1-3 and J-13-1 were identified as Pseudomonas spp. by comparing their morphological and biochemical characteristics (see Table 4) to the literature information (Krieg \& Holt 1984; Zhong 1990; Holt et al. 1994; Lu 1994; Dong \& Cai 200I).

Table 1 | Average degradation rates of succinonitrile by the isolated bacterium strians

\begin{tabular}{lll} 
Strain & $\begin{array}{l}\text { Initial concentration } \\
\text { of succinonitrile }\left(\mathbf{m g} \cdot \mathbf{L}^{-\mathbf{1}}\right)\end{array}$ & $\begin{array}{l}\text { Average degradation rate of } \\
\text { succinonitrile }\left(\mathbf{m g} \cdot \mathbf{L}^{-\mathbf{1}} \cdot \mathbf{h}^{-\mathbf{1}}\right)\end{array}$ \\
\hline $\mathrm{J}-1-3$ & 2,000 & 128 \\
& 4,000 & 194 \\
& 6,000 & 204 \\
$\mathrm{~J}-13-1$ & 6,000 & 507 \\
& 8,000 & 612 \\
& 10,000 & 623 \\
\hline
\end{tabular}


Table 2 | Biodegradation kinetic equation of succinonitrile by the isolated bacterium strains

\begin{tabular}{lllll} 
Strain & $\begin{array}{l}\text { Initial concentration of } \\
\text { succinonitrile }\left(\mathbf{m g} \cdot \mathbf{L}^{-\mathbf{1}}\right)\end{array}$ & Kinetic equation & Half life $\boldsymbol{t}_{\mathbf{1 / 2}}$ (h) & Correlation coefficient $(\boldsymbol{r})$ \\
\hline $\mathrm{J}-1-3$ & 2,000 & $\ln C=-0.1417 t+7.894$ & 6.72 & 0.9583 \\
& 4,000 & $\ln C=-0.1797 t+9.101$ & 8.35 & 0.9057 \\
& 6,000 & $\ln C=-0.0816 t+9.0519$ & 13.4 & 0.9561 \\
$\mathrm{~J}-13-1$ & 6,000 & $\ln C=-0.1942 t+9.1105$ & 5.7 & 0.9488 \\
& 8,000 & $\ln C=-0.1316 t+9.1486$ & 6.5 & 0.9623 \\
& 10,000 & $\ln C=-0.498 t+9.7947$ & 5.7 & 0.9276 \\
\hline
\end{tabular}

Table 3 | Biodegradation kinetic parameters of succinonitrile by the isolated bacterium strains

\begin{tabular}{lll} 
Strain & $\boldsymbol{R}_{\max }(\mathbf{1} / \mathbf{h})$ & $\boldsymbol{K}_{\mathbf{s}}(\mathbf{m g} \mathbf{/ L})$ \\
\hline J-1-3 & 0.323 & 837.1 \\
J-13-1 & 0.37 & 906.5 \\
\hline
\end{tabular}

\section{Succinonitrile degradation with immobilized grains}

The shaker tests showed that the PVA-IMG grains tended to inflate and break down, thus not suitable for practical application. As a result, only the SA-IMG and MPVAIMG grains were employed to degrade succinonitrile. Figure 8 shows that during the reaction course of $24 \mathrm{~h}$, the SA-IMG grains could achieve a complete removal of succinonitrile after $20 \mathrm{~h}$, while the MPVA-IMG grains achieved only $70 \%$ succinonitrile removal under identical experimental conditions. It is seen that the SA-IMG was more effective than the MPVA-IMG, probably because the SA-IMG was more permeable to the substrate. In the late period of reaction, some MPVA-IMG grains started to inflate and break down, however. Therefore, sodium alginate is preferred to PAV for strain immobilization.

\section{Effect of initial succinonitrile concentration}

Figure 9 shows the degradation of succinonitrile at different initial concentrations (i.e., 30, 3,000, and 5,000 mg/L) by the SA-IMG grains ( 1 and $2 \mathrm{~g} / \mathrm{L}$ ) as a function of reaction time. Results indicate that the SA-IMG grains were very effective in degrading succinonitrile within a broad range of

Table 4 | Major morphological and biochemical characteristics of the isolated strains

\begin{tabular}{|c|c|c|}
\hline Characteristics & $J-1-3$ & J-13-1 \\
\hline Gram & - & - \\
\hline Aerobic growth & + & + \\
\hline Catalase & + & + \\
\hline Oxidase & + & + \\
\hline Gas production from $\mathrm{NO}_{3}^{-}$ & - & - \\
\hline $\begin{array}{l}\text { Necessity of organic } \\
\text { growth nutrilite }\end{array}$ & - & - \\
\hline $\begin{array}{l}\text { Fermentation of glucose } \\
\text { (O-F medium) }\end{array}$ & - & - \\
\hline Growth at pH 4.5 & - & - \\
\hline Colony & $\begin{array}{l}\text { Round, } \Phi 0.5-1.5 \mathrm{~mm} \text {, milk white, } \\
\text { translucent, smooth surface, moist, glossy, } \\
\text { low umbo, and leaf-crack shaped fringe. }\end{array}$ & $\begin{array}{l}\text { Nearly round, } \Phi 0.5-2 \mathrm{~mm} \text {, lightly } \\
\text { honey-golden, smooth surface, moist, flat, } \\
\text { umbo at center, and leaf-crack shaped fringe }\end{array}$ \\
\hline Cell & $\begin{array}{l}\text { Rod or shot rod, partly curving, no } \\
\text { gemmae, } 0.5-0.7 \times 1.0-2.0 \mu \mathrm{m} \text {, no } \mathrm{PHB} \\
\text { accumulation in cell, polar flagella }\end{array}$ & $\begin{array}{l}\text { Rod, partly curving, no gemmae, } \\
0.4-0.6(-0.9) \times 1.0(2.2 \mu \mathrm{m} \text {, no } \mathrm{PHB} \\
\text { accumulation in cell, polar flagella }\end{array}$ \\
\hline
\end{tabular}




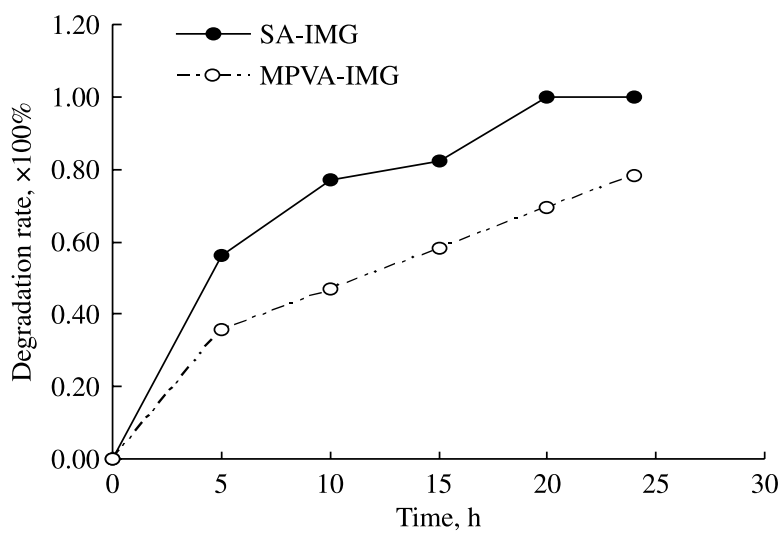

Figure 8 | Degradation of succinonitrile with IMG carriers.

initial succinonitrile concentration, achieving removal efficiencies greater than $80 \%$ after $24 \mathrm{~h}$ in all cases. In particular, at the SA-IMG concentration of $2 \mathrm{~g} / \mathrm{L}$, succinonitrile could be completely degraded even at an initial concentration as high as $5,000 \mathrm{mg} / \mathrm{L}$.

\section{Degradation stability of SA-IMG}

To examine the degradation stability of the immobilized grains, the SA-IMG was repeatedly used to degrade succinonitrile for four times. After each reaction course, the grains were taken out from the flasks, repeatedly washed with distilled water, and added into a new flask containing a fresh solution of $3,000 \mathrm{mg} / \mathrm{L}$ succinonitrile. Figure 10 shows that the SA-IMG retained its degradation efficiency after four experimental runs. In addition, the SAIMG possessed a good mechanical strength.

Results show that Pseudomonas spp are able to utilize succinonitrile as a sole source of carbon and nitrogen.

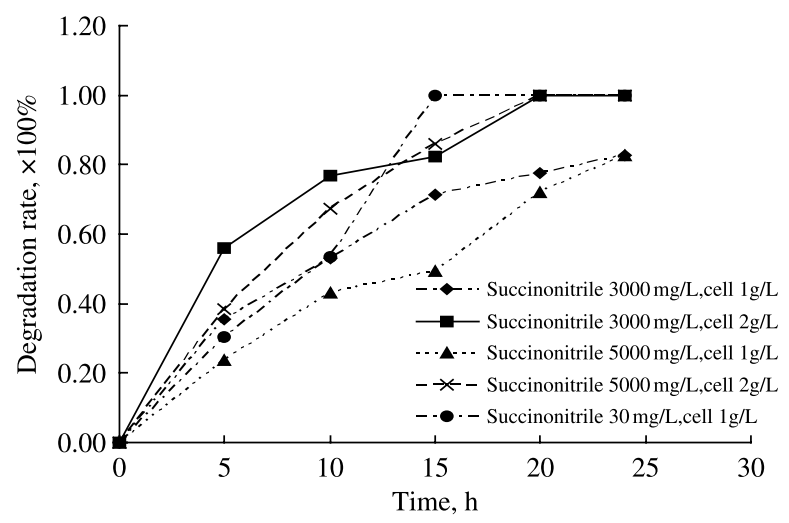

Figure 9 | Degradation efficiency of succinonitrile with different initial concentrations.

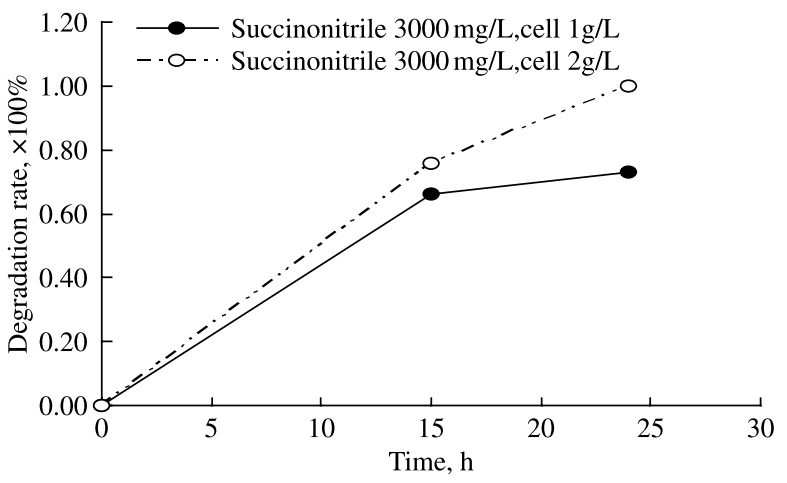

Figure 10 Degradation of succinonitrile with repeated use of SA-IMG.

According to a comparative study of the above two strains, J-13-1 has much higher degrading efficiency for succinonitrile, and with the initial concentration of succinonitrile at $6,000,8,000$ and $10,000 \mathrm{mg} / \mathrm{l}$, the degrading rates of succinonitrile by strain J-13-1 reached to $100 \%$ after $12.5 \mathrm{~h}$, $14 \mathrm{~h}$ and $16 \mathrm{~h}$, respectively.

In addition, when the bacterium entrapped and immobilized with sodium alginate was used and the concentration of the bacterium was $1 \mathrm{~g} / \mathrm{l}$ and $2 \mathrm{~g} / \mathrm{l}$, with the presence of different initial concentrations of succinonitrile at 30, 3,000, and $5,000 \mathrm{mg} / \mathrm{L}$, the degradation rate of succinonitrile was over $80 \%$. Especially at the SA-IMG grains of $2 \mathrm{~g} / \mathrm{l}$, the degradation rate of succinonitrile all can achieve $100 \%$ after $20 \mathrm{~h}$.

Results also demonstrated that modifying is necessary when PVA was used to immobilize the isolated strains, otherwise it is difficult to achieve the mechanical strength purposes. Contrasting the results of MPVA-IMG and SAIMG grains, we can see that the latter much more effective. Reusability research of SA-IMG grains in the process of succinonitrile degradation indicated that the degradation rate remains approximately the same. These results show that the SA-IMG grains is steady on biodegradability and suitable for repeat utilization.

\section{$\overline{\text { CONCLUSIONS }}$}

Two bacterium strains effective in succinonitrile degradation, named J-1-3 and J-13-1, were isolated and screened out from the treatment facilities for acrylic fiber production wastewater treatment. Both strains were identified to be Pseudomonas spp. By flask tests, the optimal growth conditions for the two strains was determined as follows: incubation 
temperature $30^{\circ} \mathrm{C}$, shaker rotary speed $250 \mathrm{r} / \mathrm{min}$, inoculum percentage $0.1 \%$, and initial medium $\mathrm{pH} 6$. Under the optimal conditions, both strains showed a high degradation efficiency for succinonitrile, especially the strain J-13-1.

The SA-IMG grains were superior to the PVA-IMG and MPVA-IMG grains in terms of succinonitrile degradation efficiency and mechanical strength. Within a very broad range of initial succinonitrile concentration (i.e., 30$5,000 \mathrm{mg} / \mathrm{L})$, the SA-IMG could degrade more than $80 \%$ of succinonitrile after a reaction time of $24 \mathrm{~h}$. In addition, the SA-IMG retained a good mechanical strength and degradation efficiency after repeated use.

\section{ACKNOWLEDGEMENTS}

The authors gratefully acknowledge the financial support from the National Natural Science Foundation of China (No.50008011), Key Technologies R\&D Program (No.2006BAJ08B00), and the Program of STCSM (No.05QMX1453) for this work.

\section{REFERENCES}

Akamatsu, S., Bottin-Rousseau, S., Perrut, M., Faivre, G., Witusiewicz, V. T. \& Sturz, L. 2007 Real-time study of thin and bulk eutectic growth in succinonitrile-(D)camphor alloys. J. Crystal Growth 299, 418-428.

Anselmo, A. M. 1985 Degradation of phenol by immobilized cells of Fusarium flocciferum. Biotechnol. Lett. 7(12), 889.

Bushnell, L. D. \& Haas, H. F. 194I The utilization of certain hydrocarbons by microorganisms. J. Bacteriol. 41(5), 653-673.

Dhillon, J. K. \& Shivaraman, N. 1999 Biodegradation of cyanide compounds by a Pseudomonas species (S1). Can. J. Microbiol. 45, 201-208

Dong, X. Z. \& Cai, M. Y. 20or Identification Handbook of Normal Bacteria System. Science Press, Beijing, pp. 162-163.

Hadri, L. E., Chanas, B. \& Ghanayem, B. I. 2005 Comparative metabolism of methacrylonitrile and acrylonitrile to cyanide using cytochrome P4502E1 and microsomal epoxide hydrolasenull mice. Toxicol. Appl. Pharmacol. 205, 116-125.

Hayashi, A., Aoyagi, H., Kinjyo, K., Yoshimura, T. \& Tanaka, H. 2007 Development of an efficient method for screening microorganisms by using symbiotic association between Nasutitermes takasagoensis and intestinal microorganisms. Appl. Microbiol. Biotechnol. 75, 1437-1446.

Huang, C. P., Wang, Y. J. \& Chen, C. Y. 2007 Toxicity and quantitative structure-activity relationships of nitriles based on
Pseudokirchneriella subcapitata. Ecotoxicol. Environ. Saf. 67, 439-446.

Holt, J. G., Krieg, N. R. \& Sneath, P. H. A. 1994 Bergey's Manual of Determinative Bacteriology, 9th edition. The Williams \& Wilkins Co., Baltimore, pp. 93-94, 151-168.

Hu, J. J. \& Zhou, Q. Y. 1988 Environmental Engineering Microbiology. Higher Education Press, Beijing, pp. 26.

Krieg, N. R. \& Holt, J. G. 1984 Bergey's Manual of Systematic Bacteriology, (Vol. 1). The Williams \& Wilkins Co., Baltimore, pp. 140-219.

Lin, Y. H., John, H. S., Shih, W. C. \& Chen, K. C. 2006 Development of a novel microorganism immobilization method using anionic polyurethane. J. Appl. Polym. Sci. 99(3), 738-743.

Li, T. G., Liu, J. X., Bai, R. B., Ohandja, D. D. \& Wong, F. S. 2007 Biodegradation of organonitriles by adapted activated sludge consortium with acetonitrile-degrading microorganisms. Water Res. 41(15), 3465-3473.

Lu, Z. Z. 1994 Bacteritaxology [M]. Wuhan University Press, Wuhan, pp. 88-93, 340-358.

Nawaz, M. S., Chapatwala, K. D. \& Wolfram, J. H. 1989 Degradation of acetonitrile by Pseudomonas putida. Appl. Environ. Microbiol. 55, 2267-2274.

Nawaz, M. S., Davis, J. W., Wolfram, J. H. \& Chapatwala, K. D. 199I Degradation of organic cyanides by Pseudomonas aeruginosa. Appl. Biochem. Biotechnol. 28(29), 865-875.

Su, J. F., Ma, F., Hou, N., Wang, C., Wang, H. Y. \& Chang, Y. G. 2006 Isolation and identification of phenol degradation bacteria with high efficiency applied in immobilized biological technique. J. Shenyang Jianzhu Univ. Nat. Sci. 22(2), 307-310.

Toniazzo, G., Lerin, L., Oliveira, D. D., Dariva, C., Cansian, R. L., Padilha, F. F. \& Antunes, O. A. C. 2007 Microorganism screening for limonene bioconversion and correlation with RAPD markers. Appl. Biochem. Biotechnol. 132(1-3), 1023-1033.

Wang, C. C., Lee, C. M. \& Cheng, P. W. 20or Acrylonitrile removal from synthetic wastewater and actual industrial wastewater with high strength nitrogen using a pure bacteria culture. Water Sci. Technol. 43(2), 349-354.

Wang, C. C., Lee, C. M. \& Chen, L. J. 2004 Removal of nitriles from synthetic wastewater by acrylonitrile utilizing bacteria. Hazard. Subst. Environ. Eng. 39(7), 1767-1779.

Yamada, H., Asano, Y. \& Hino, T. 1979 Microbial utilization of acrylonitrile. J. Ferment. Technol. 57(1), 8-14.

Yamada, H., Asano, Y., Hing, T. \& Tani, Y. 1980 Microbial utilization of glutaronitrile. J. Ferment. Technol. 6, 495-500.

Yao, H., Sun, X. D., Ma, F. \& Li, G. B. 2003 Reuse of nonbiodegradable organic wastewater by immobilized biological technology. J. Harbin Inst. Technol. 35(12), 1471-1473.

Zhang, Y. L. 1999 Study on the Treatment Technology for the Biorefractory Organic Wastewater (Acrylic Fiber Wastewater) and Biodegradation of Organic Pollution. Tongji University, Shanghai, pp. 77-79.

Zhong, J. Z. I99o Micotaxology [M]. Fudan University Press, Shanghai, pp. 21-23, 92, 99. 